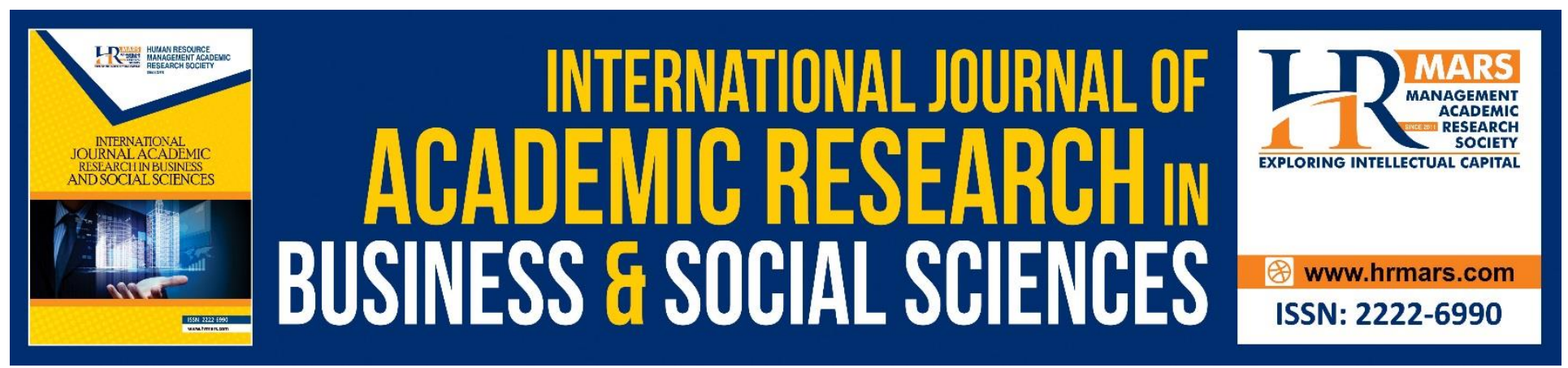

\title{
Executive leadership performance according to Culture Variety in Iranian organizations (Case Study: Social Security Insurance of Main Provinces in Iran)
}

\section{Asadi Rahil}

To Link this Article: http://dx.doi.org/10.6007/IJARBSS/v9-i3/5749

DOI: $\quad 10.6007 /$ IJARBSS/v9-i3/5749

Received: 13 Feb 2019, Revised: 27 Feb 2019, Accepted: 19 March 2019

Published Online: 26 March 2019

In-Text Citation: (Rahil, 2019)

To Cite this Article: Rahil, A. (2019). Executive leadership performance according to culture variety in Iranian organizations (Case Study: Social Security Insurance of Main Provinces in Iran). International Journal of Academic Research in Business and Social Sciences, 9(3), 828-841.

\section{Copyright: (C) 2019 The Author(s)}

Published by Human Resource Management Academic Research Society (www.hrmars.com)

This article is published under the Creative Commons Attribution (CC BY 4.0) license. Anyone may reproduce, distribute, translate and create derivative works of this article (for both commercial and non-commercial purposes), subject to full attribution to the original publication and authors. The full terms of this license may be seen at: http://creativecommons.org/licences/by/4.0/legalcode

\section{Vol. 9, No. 3, 2019, Pg. 828 - 841}

Full Terms \& Conditions of access and use can be found at http://hrmars.com/index.php/pages/detail/publication-ethics 


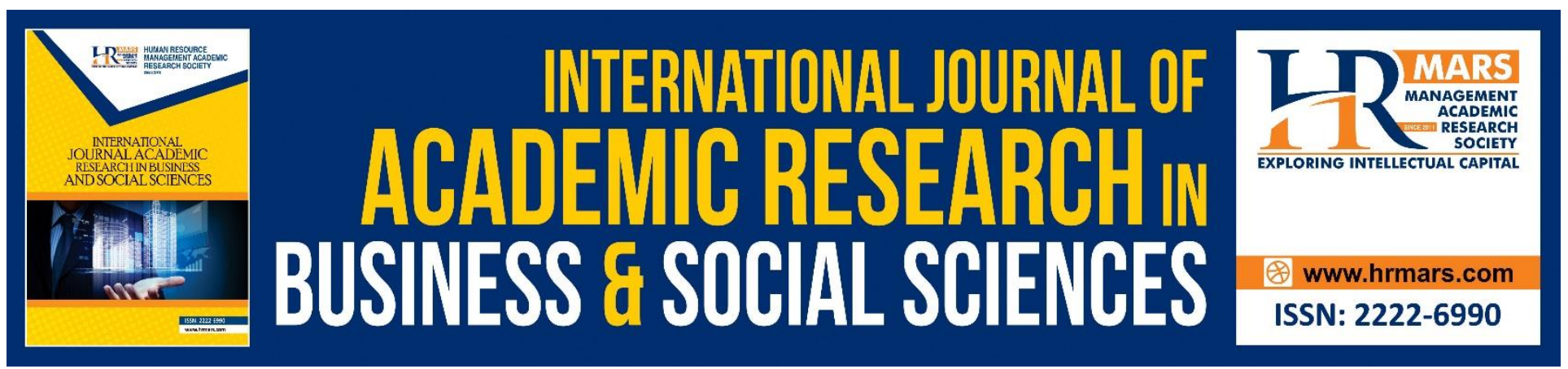

\title{
Executive leadership performance according to Culture Variety in Iranian organizations (Case Study: Social Security Insurance of Main Provinces in Iran)
}

\author{
Asadi Rahil \\ Ph.D. Student at ASE, Bucharest University of Economic Studies, Romania, Bucharest
}

\begin{abstract}
Today's organizations are face with many challenges, such as maintaining the quality through reduced resources, improve financial management, to receive more research support, development of new intrusions and skills, assist members to cope with the increasing work pressure, maintaining motivation and work spirit, innovation in education and research. The purpose of this investigate research is to analysis and examine the executive leader's behaviors and the managers with the culture difference in Iranian organizations based on Hofstede's cultural indicators in the large companies' contacts of main provinces of Iran. The current study applied and descriptive-correlative and analyses the situation on of executive leaders in different culture throw the work at large companies with the employees by different cultures and behaviors. The statistical population of the survey is carried out by the employees of the central offices of Social Security Insurance, which was reported in 2017 by more than 6,000 people population. The sample size is 351 according to the Morgan table and selected by proportional random sampling. The main method of gathering the information's in this research is with the designed questionnaire combination of a researcher idea and Hofstede's theory. Also, the validity of the questionnaire was verified by factor analysis ANOVA and 6 factors explained the total of variance of 51.59\%. The calculated reliability coefficient for the culture questionnaire by the Cronbach coefficient test was 0.795 , which shows an acceptable reliability. The results of this research showed that there are different cultures based on geographic regions and it has direct impacts on the behaviors of employees and executive leader's performance. Finally, some suggestions for leaders and managers were explained with regard to the existing cultural differences.
\end{abstract}

Keywords: Culture Difference, Leadership and Culture, Leaders, Behaviors

Introduction

In the point view of leaders one of the most important issues in communicating with employee, is about the way of their performance and their behaviour in organizations. As we know, the behavior 
of individuals originates from their culture, so the culture and behaviour having strong relation as we cannot define the behavior of a person apart from his culture. It can be said that the behavior of the person and the actions he/she performs is rooted in his/her culture, and its reflects of the culture. According this we can say, the cognition and understanding the people's culture for better communication and leading is the needs of leaders and managers at the organization and social institutions. (Robbins, 2017) about the culture difference and impact of culture on the quality and quantity performance of workers says as we know, the French are different from the British, the Arabs with the Canadians, the Germans with the Australians, the Japanese with the Americans and the Iranians, as well as with the other countries, This difference is due to cultural differences that managers and leaders needs to understand and make them familiar with different cultures to improve the performance and at the top of their work.

In some cultures, at first the person and then group dimension is considered, and this leads to the independence of team members, but this issue may be annoying for those who have grown in a collectivist or group-oriented culture. Therefore, it can be said that any organization have its own culture and that describes the proper behavior for its members and it is the basis for rules and regulations. Culture effects is on the sustainable laws and unauthorized regulations and as a specific language, in the communication between the members plays a key role and facilitates interaction between individuals. (Rezaeian, 2004) found that organizational culture and its dimensions have a significant relationship with the productivity of human resources in Kurdistan Energy Services Company. (Rezaeian, 2004), The results showed a positive and significant relationship between organizational culture and job satisfaction, and there is a reciprocal relationship between organizational culture and job burnout. according his comparative analysis for the impact of work culture in performance of employees at the governmental organizations of Isfahan and Khuzestan provinces, based on the Hofstede cultural dimension model, it showed that there's a significant difference in four dimensions of masculinity, ambiguity, power distance and generosity in terms of the culture difference between the two provinces, but there was no significant difference in individualism dimensions among the employees at organizations.

As we know, the priority of doing any action in the organization, it is necessary to pay attention to their organizational culture, because by leverage of culture, we can simply facilitate the implementation of changes and help to shape and make the new directions in the organization. In addition of the impact of culture in making change, also it is helpful to overcome worries, anxieties and reduce the work pressures in the organization (Bolt, 2007).

Also, leaders need to recognize the culture in order to integrate people with different cultures, to better fulfil their tasks and organize them to communicate better and better with others. Considering that Iran has different subcultures in different geographic regions, it is necessary to recognize existing subcultures and cultural differences for managers and leaders of Iranian organizations so that with the influence of culture in management procedures they can achieve the best performance and productivity in their organization. Considering the above mentioned issues, we can say today the culture is one of the most important factors affecting the functioning of organizations and the recognition of culture factors in organization and society is one of the essential requirements for leaders a to identify the behaviour of employees according the cultural differences and lead their best practices and make the right decisions and policies for the organization. In this study, cultural 
factors based on six dimensions of Hofstede's phenomenon include masculinity, grouping, ambiguity, power distances, generosity and loyalty ,bounded in the central offices of Social Security Insurance organization of the main provinces in the geographical directions of Iran, between cities: Tehran, Isfahan, Khorasan Razavi, Mazandaran, Azarbaijan, Khuzestan, were investigated in order to determine the level of cultural factors in strategies and decisions, differences and applied cultural factors, and established better communication with them in terms of recognizing the culture of individuals and how they behave. According to the explanation, the main issue of this research is the study of management and leaders' performance in the context of culture in Iranian organizations based on Hofstede cultural indicators in Iran Social Security Insurance organization.

In this context, the following questions will be answered.

- What are the cultural factors levels in the studied organizations?

- Do the cultural factors are different in the term of generation at the studied organizations?

- Are there significant differences between cultural indices of masculinity, grouping, uncertainty avoidance, power distance, long-term orientation and constraint among studied organizations?

- What are the appropriate management methods according to the results of the third question?

\section{Leadership and Culture}

Taylor (1871) describes one of the first definitions of culture as follows: A complex set of knowledge, beliefs, arts, ethics, laws, values, and any other ability that human beings achieves as a member of society. Culture is a powerful way of explaining individual and group differences in behavioral patterns in different countries. Behaviours that are obvious and normal in a culture can be strange and alien to another culture. Even the daily behaves such as greeting to people of different cultures are not the same. To achieve a deeper understanding of how culture impacts on the behavior of organizations, study and analysis the cultural difference is very important) (Rezaeian, 2004), Culture can be defined as mental planning (Hofstede, 1980). Culture, it's not an only the distinctive life style between human being and animal, but is a kind of demographic and distinctive life style between the different groups and communities in society. Therefore, we can speak of a culture as a congregation, a nation, a tribe, a religious group, or a continent. From this perspective, each particular person is a specific cultural product in which area he lives (Rezaeian, 2004), According to the results of the research, culture is divided into seven elements of religion, language, values, norms, status and role in society, social organization and cultural integration.

Different frameworks are designed to identify the culture, (Jessor, 1962). introduced the sixdimensional structure in cultural orientation, which are relationship with nature, time orientation, human nature, orientation of effort, relationships between individuals and spatial orientation. Different frameworks have been designed for the study of culture by Scientifics, such as (Trompenaars \& Hampden-Turner, 2004) divided the cultural values to 7 dimensions of universalism or generalism versus of specificism, individualism versus collectivism, neutrality and indifference in emotional, acquired versus assignable, particular (limited) versus scattering, internal conduction from outer conduction and consecutive time against synchronization (Matsumoto \& Hwang, 2013) used the concept of upper and lower tissues to explain differences in communication between individuals and also pointed out to the Hofstede's cultural dimensions. 
Considering that, the Hofstede's cultural dimensions is expressed at national level and is one of the most important and comprehensive theories on the framework of cultures. At this research The Hofstede theory used to analysis the impact of culture on the selected organization. Hofstede studied the dimensions of cultural values and identified six dimensions for the culture. These dimensions are: 1. Individualism (The degree of individualism that individuals in a country prefer to act individually rather than grouping) instead of socialism and grouping (its regards the individuals who likes to act in a group). 2. Avoiding uncertainty or ambiguity: the degree that people of the community prefer structured and obvious situations rather than unstructured and vague conditions. 3. The power gap: the degree of inequality of power and wealth among the people of country that others have accepted it as a normal condition. 4. Masculinity (Men's values are emphasized by expressing assertive and existence, performance, decisiveness, success, and competition) against femininity (The emphasis on women's values includes Quality of life, maintaining personal relationships, services, care and solidarity) 5. Long-term orientation or the dynamics of the Confucian School, all of them are geared towards long-term future goals and focused on long-term goals with emphasis on the dignity of life in this world with savings and perseverance as a virtue behaviours. (Hofstede, 1984). 6. Constrain society against unconstraint societies. This is followed by theoretical texts of happiness, and unconstrained societies are referred to societies in which they relatively free to achieve the basic and natural demands associated with enjoyment and entertainment and at the constrain society, achieve the satisfying needs is with the norms Rigidly adjusts and controls. Despite the cultural differences, it can predict partially people's behaviour, the decision-making style and organizational structure, and with best way governed and managed by this prediction. Many scholars believe that the success of Japanese management is due to the existence of unique compromise and institutionalized principles in Japan that culture has been rooted in these institutional agreements and principles, and it is difficult to separate these two categories. German companies are paying too much attention to Technique and technology, and German companies are usually expected to make money, not through buying and selling businesses but with the create and make something new. In Denmark, the Morgenavisen newspaper first noticed the role of culture in the ability of Danish companies in the field of competition, and warned that the competitiveness of these companies is limited by the traditional cultural influence of Janteloven, which means that you must be content and satisfied with the low profits and you should not seek superiority over others. The newspaper claims that Danish companies are not impressed by their cultural beliefs in compared to other European rivals. The purpose of these examples is to emphasize the fact that each country, even can say that each region has its own specific cultural and institutional features that can be the source of success in terms of competition with others. What in the past has been the source of excellence and success in the field of competition, can also in the future become a point of weakness. Therefore, managers must assess and measure the extent to which the culture influences and influences the company's efforts and responses to the strategic needs (present and future), (Susan \& Barsoux, 2014). Each of the cultural indicators Hofstede can be a predictor of the specific behavior of individuals, which can on the basis selected the management. In individualism, the initiative is important, and the priority and choice are respected, and employee assessment and remuneration are based on the individual agreement about the goal. Can say the Individuals have goals that are central, and they are dominant, and individuals defend their own interests. But in grouping, the group and membership in a group are 
most important, it is relationship -oriented and the relationship is based on the being a member or not. The organization is mostly look like a family and the employee performance are based on the commitment, loyalty, and sense of duty and group engagement.

Low power distance organizations are decentralized with the flat structures, the number of supervisory staff is low, and decisions making are collaborative. High-power distance organizations are concentrated in hierarchical structures, there are a large number of superintendents working there and the manager makes a decision. Ambiguity and uncertainty plays an important role in risk and it is sometimes synonymous each other, if it is strong and high so employees are worried about doing things, they do not tolerate the beginning of a new work without comprehensive research, and they will oppose the changes, and they are risk averse, there is less workforce displacement in such kind of organizations but in an organizations with the low and poor ambiguity, employees are eager to accept the risk associated with the unknown, the activities has less structured and framework, with more general approach, flexibility and variability are more and behaviours' propagandist, traditional customs is less. In an organization with the state of man domination, and masculinity the progress is important in terms of revenue, reputation, and competitiveness. Individuals employee tend to take decisions independently. Managers believe employees do not like work and should be controlled, and men occupy managerial occupations in the organization. In the organizations with the orientation of feminism and state of women's affairs, the employs are care about well-being and quality of products, managerial jobs are also given to women, and job stress is low, they value cooperation, friendly atmosphere and with the group decision-making.

The foresight perspective can be seen as a futurism and anxiety and concerns for the future, and managers are value the economy, firmness and resilience, and how their actions are assessed for the future, and for the short-run index they focus on seasonal and annual profit outcomes. These are can be expressed as the behaviours of manager in this type of organization. Also, employee evaluation is reviewed periodically and the traditions are sacred and values are oriented toward the past and future (Rezaeian, 2004), In an organization with the Coherence benchmark index can be highlighted the employees to be very unhappy, joblessness, disappointment in activities, enjoyment of leisure, low interest in sports, and with the high control forces. And opposite that the Indicators without constraints has very happy people, leisure and sports Important, talking and freedom of opinion are important and they must enjoy and satisfied their work without a certain framework.

Also, there are four types of cultural indicators which they are plays a vital role in management styles. Likert management styles are:

1. The Exploitative or Authoritative Leadership Style

: in this style which the duties and expectations are clear, certain instructions are issued, and subordinates are required to act in accordance with the rules and regulations, there is no trustworthiness of the treasurer and communications are up-and-down, the employee has no freedom to discuss or complain.

2. Benevolent or Autocratic Leadership Style

It's kind of supporting styles in which the manager has relative reliance on subordinates, takes care of their well-being and creates a friendly atmosphere, however, the organization's policy and overall decisions are made at the high levels. 


\section{Advisory or consultative Leadership Style}

In this style the manager has a significant assurance to the subordinates, the organization is decentralized and manager try to determines the challengeable goals and demands to performance modification. the interaction between the superiors and subordinates is based on the trust and communication is in between the both cases up and down.

4. Democratic Leadership Style

We can say it is kind of, participatory style, in which there is full trust and confidence to subordinates, communications are in between the all level of employees, they want to consult with subordinates and use their opinions before making a decision. Organizational atmosphere is fully friendly.

\section{Research Methodology}

The present research is applied in terms of its purpose and it is descriptive-correlative in nature. On the other hand, Iran has different subcultures in different geographic regions. Considering that the subject of culture was considered in this research, research should be carried out in different regions with different subcultures, and given the wide range of Social Security Insurance companies throughout Iran, this research was carried out at Iran Social Security Insurance Company. Accordingly, the statistical population of this research is from all employees of the central offices of the main provinces city of the country, including the Khorasan Razavi province, Mazandaran, Azarbaijan, Khuzestan and Isfahan, and The Social Security Insurance company of Tehran the capital of the country, has been gathered and all of them are the subsidiaries of Iran Social Security Insurance Company.

The number of staff in these centres was 4,000 in 2014. In this study, according to the 4000-strong population, and according to the Morgan sample size, 351 people were given the geographical distribution and the possibility of reducing the responders examined 351, all 400 questionnaires were distributed and 352 questionnaires completed were returned. In this research, due to the different regions and number of employees in these areas, a proportional random sampling method was used and the sample size of each region was determined in relation to the total population of the statistical population of that area, and the sample of each region was also determined by the method Simple Random Selection. The required information in this research was collected by library, field and also secondary data. For data gathering used the designed questionnaire is according the Hofstede Cultural Dimension Questionnaire, Also, these questionnaires included items related to demographic variables. In this research, for analysis, the data using the descriptive and inferential statistical methods. The validity of the culture questionnaire was verified by factor analysis and it was shown that the six factors identified were $51.59 \%$ of the total variance. The calculated reliability coefficient for the culture questionnaire is equal to 795.90 and for the cultural factors of Masculinity (maledominated) was 0.863 , the grouping was 7.742 and the Uncertainty avoidance 757.7 , power distance was 791 , the Long-term orientation was 778 and the constraint was 7,800 . Shows good reliability and correlation.

\section{Research Findings}

At this survey, the demographic variables showed that $56.2 \%$ of the total respondents (352) were male and $43.4 \%$ were female. Most respondents with a high percentage of 3.56 have a bachelor's 
INTERNATIONAL JOURNAL OF ACADEMIC RESEARCH IN BUSINESS AND SOCIAL SCIENCES

Vol. 9, No. 3, March, 2019, E-ISSN: 222 2-6990 @ 2019 HRMARS

degree. Also, the majority of respondents are 179 in the age range of 25 to 35 years old. To answer the first question, what are the level of cultural factors in that studied provinces?

For answer to this question, the One-sample T-test used to measure the level of cultural indicators with respect to the average (Valuation of the Likert spectrum for the items of the questionnaire is from 1 to 5, which is 3 for the average level of cultural indicators). According to Table 1, the mean of masculinity 3.05, grouping 4.013, uncertainty avoidance 4.158, power distance 2.568, Long-term orientation 4.121, and constraint of 2.965. The significance level of T-test about grouping, uncertainty avoidance, power distance and long-term orientation are equal to zero and less than 0.05 that is shows the obtained meanings have a significant difference with the average level of 3 , and regarding the factors of masculinity and constraint, the significance level of the T-test is more than 0.05 , so we can say that the mean of these two dimensions is equal to the average. Also, according to the confidence level and the upper and lower limit values, the means of grouping, uncertainty avoidance and long-term orientation are higher than the average and the power distance is less than average.

Table 1: Sample T test results for cultural factors

\begin{tabular}{|c|c|c|c|c|c|}
\hline \multirow[t]{2}{*}{ Variables } & \multirow[t]{2}{*}{ Means } & \multirow[t]{2}{*}{ T-test values } & \multirow{2}{*}{$\begin{array}{l}\text { Significant level } \\
\text { of T-test }\end{array}$} & \multicolumn{2}{|c|}{$\begin{array}{l}\text { The confidence level of } \\
95 \%\end{array}$} \\
\hline & & & & $\begin{array}{l}\text { Lower } \\
\text { limit }\end{array}$ & $\begin{array}{l}\text { Upper } \\
\text { limit }\end{array}$ \\
\hline Masculinity & 3.05 & 1.185 & 0.237 & -0.033 & 0.135 \\
\hline Grouping & 4.013 & 34.531 & 0.000 & 0.955 & 1.071 \\
\hline $\begin{array}{l}\text { Uncertainty } \\
\text { avoidance }\end{array}$ & 4.158 & 47.102 & 0.000 & 1.109 & 1.206 \\
\hline Power distance & 2.568 & -12.203 & 0.000 & -0.5 & -0.361 \\
\hline $\begin{array}{l}\text { Long-term } \\
\text { orientation }\end{array}$ & 4.121 & 40.435 & 0.000 & 1.066 & 1.175 \\
\hline Constraint & 2.965 & -0.981 & 0.327 & -0.104 & 0.035 \\
\hline
\end{tabular}

To answer the second question and find out are the cultural factors different based on gender in the studied provinces, the average and means of cultural factors were analysed and compared by independent T-test of the two sex groups of men and women. As it is shown below, at Table 2, according to the lower significance level of cultural at factors of masculinity, grouping and long-term orientation from t-test 0.05 , we can say that the Mean difference between of cultural factors of masculinity, grouping and long-term orientation in two male and female gender groups is significant and in factors cultural Uncertainty avoidance, power distance and constraint There is no significant difference between male and female gender and with regard to the upper and lower limit at the level of $95 \%$ confidence, the level of cultural factors for the variables: masculinity, grouping and Longterm orientation are more in men than women. 
INTERNATIONAL JOURNAL OF ACADEMIC RESEARCH IN BUSINESS AND SOCIAL SCIENCES

Vol. 9, No. 3, March, 2019, E-ISSN: 222 2-6990 @ 2019 HRMARS

Table 2: T-test of independent societies to examine the difference between cultural factors in two gender groups.

\begin{tabular}{|c|c|c|c|c|c|}
\hline \multirow{2}{*}{ Variables } & \multirow{2}{*}{ T-test values } & \multirow{2}{*}{ Degrees of freedom } & \multirow{2}{*}{ Significant level of T-test } & \multicolumn{2}{|c|}{ The confidence level of $95 \%$} \\
\hline & & & & Lower limit & Upper limit \\
\hline Masculinity & 11.913 & 350 & 0.00 & 0.726 & 1.013 \\
\hline Grouping & 3.457 & 350 & 0.001 & 0.088 & 0.317 \\
\hline Uncertainty avoidance & 1.063 & 335.205 & 0.288 & -0.044 & 0.149 \\
\hline Power distance & 1.433 & 341.488 & 0.153 & -0.037 & 0.238 \\
\hline Long-term orientation & 3.977 & 306.563 & 0.000 & 0.111 & 0.33 \\
\hline Constraint & 1.304 & 331.679 & 0.193 & -0.233 & 0.047 \\
\hline
\end{tabular}

To answer the third question, which shows that, are there any significant differences between the cultural indices of masculinity, grouping and uncertainty avoidance, power distances, and long-term orientation, constraint between the provinces or no? used the One-way analysis of variance ANOVA and Tukey's test analysis.

Table 3 shows the average cultural factors of the respondents in the studied provinces including Tehran, Isfahan, Khorasan Razavi, Mazandaran, Azarbaijan, Khuzestan.

According to Table 4 and the result of confidence level, there is no significant difference in the mean of the variables grouping and the power distance of the provinces study. The other cultural factors including masculinity, uncertainty avoidance, long-term orientation, and constraint, they have significant differences among the studied provinces. The Tukey's test was performed to determine which province was better in terms of these factors.

Table3: Mean of the cultural factors in the studied provinces

\begin{tabular}{|l|l|l|l|l|l|l|}
\hline $\begin{array}{l}\text { Variables } \\
\text { Mean }\end{array}$ & Tehran & Isfahan & $\begin{array}{l}\text { Khorasan } \\
\text { Razavi }\end{array}$ & Mazandaran & Azarbaijan & Khuzestan \\
\hline Masculinity & 3.2731 & 3.0309 & 2.7214 & 3.2154 & 2.8298 & 3.0714 \\
\hline Grouping & 4.0718 & 3.9979 & 4.2500 & 4.2518 & 4.2270 & 4.2778 \\
\hline $\begin{array}{l}\text { Uncertainty } \\
\text { avoidance }\end{array}$ & 3.9487 & 4.1708 & 3.9097 & 3.9965 & 4.0248 & 3.9524 \\
\hline Power distance & 2.4923 & 2.6314 & 2.4613 & 2.6475 & 2.5258 & 2.6973 \\
\hline $\begin{array}{l}\text { Long-term } \\
\text { orientation }\end{array}$ & 4.1354 & 3.9309 & 4.3167 & 4.3149 & 3.8681 & 4.2000 \\
\hline \begin{tabular}{l} 
Constraint \\
\hline
\end{tabular} & 3.2198 & 2.7601 & 3.1368 & 3.1368 & 2.6657 & 3.1156 \\
\hline
\end{tabular}


INTERNATIONAL JOURNAL OF ACADEMIC RESEARCH IN BUSINESS AND SOCIAL SCIENCES

Vol. 9, No. 3, March, 2019, E-ISSN: 222 2-6990 @ 2019 HRMARS

Mean of the cultural factors in the studied provinces

\section{Mean of the cultural factors}

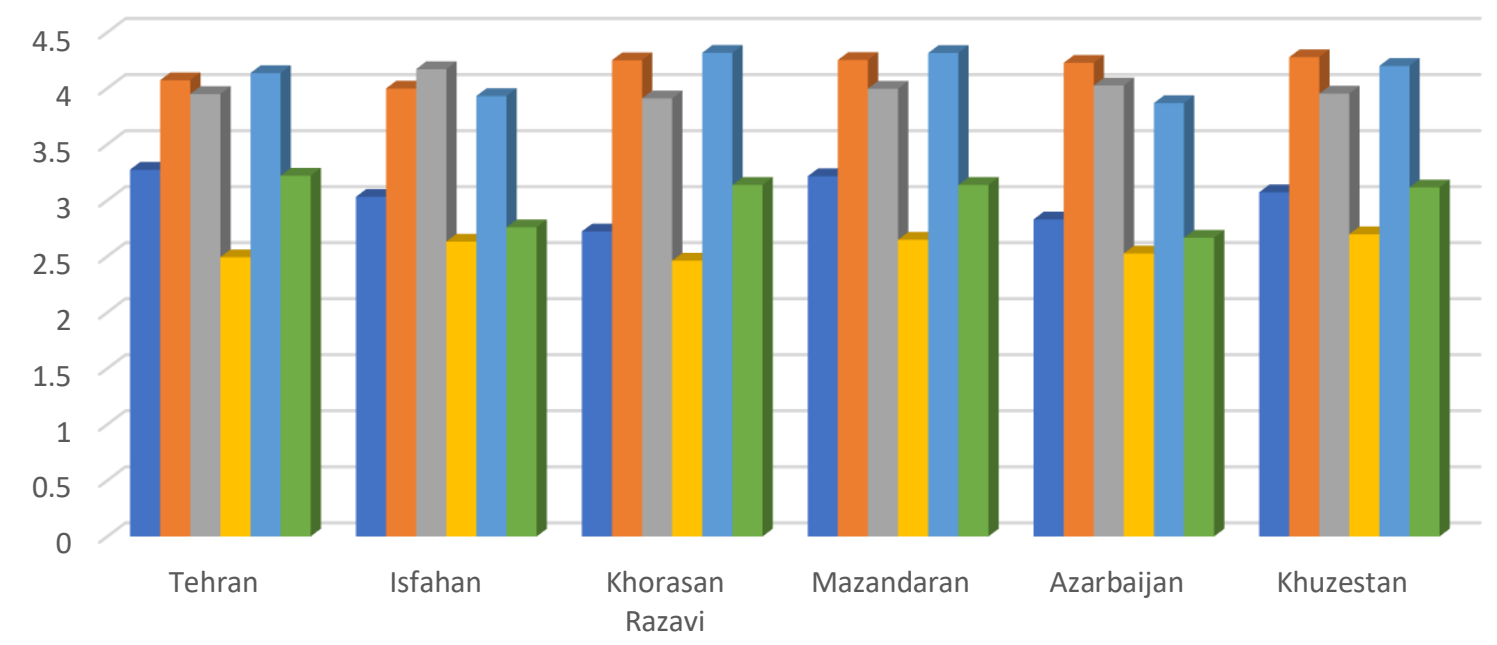

Masculinity $\square$ Grouping $\square$ Uncertainty avoidance $\square$ Power distance $\square$ Long-term orientation $\square$ Constraint

Table 4: ANOVA, Analysis of variance of the cultural factors at the studied provinces

\begin{tabular}{|l|c|c|}
\hline Variables & F- ratio & Significant level \\
\hline Masculinity & 3.512 & 0.02 \\
\hline Grouping & 1.678 & 0.125 \\
\hline Uncertainty avoidance & 3.520 & 0.02 \\
\hline Power distance & 0.954 & 0.456 \\
\hline Long-term orientation & 7.341 & 0.00 \\
\hline Constraint & 6.312 & 0.00 \\
\hline
\end{tabular}

Analysis of variance of the cultural factors at the studied provinces

\section{Analysis of variance of the cultural factors}

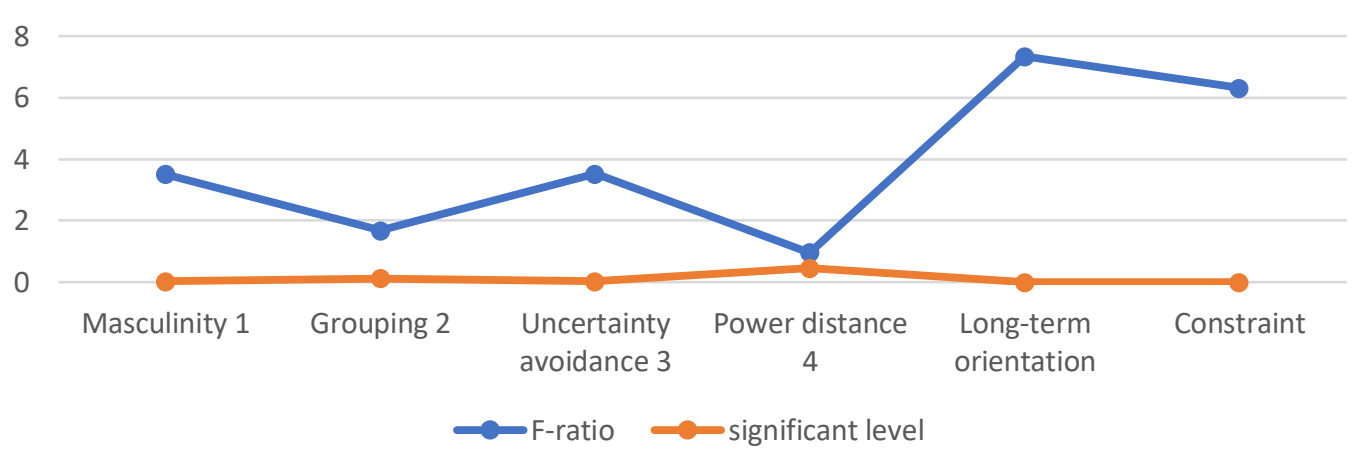

Tukey's test and analysis of variance showed that there is a significant difference between the Tehran province's masculinity index and Khorasan Razavi, but it's not high difference level of masculinity than 
the other provinces. Khorasan Razavi has a significant difference with Tehran and Mazandaran provinces, and its level of masculinity is less than the other two provinces, and Mazandaran province with Khorasan province Razavi is a significant difference and it has high masculinity. For the variable uncertainty avoidance there is no significant difference between the province of Tehran and Azarbaijan with the rest of the studied provinces; Isfahan province has a significant difference with the provinces of Khorasan Razavi, Mazandaran and Khuzestan, and Its level of Uncertainty avoidance is higher, and the provinces of Khorasan Razavi, Mazandaran and Khuzestan with Isfahan province has a significant difference and their level of uncertainty avoidance is lower and they are not significantly different from the rest of the studied provinces. About the long -term orientation index, there is no significant difference regarding this variable between Tehran province with the rest of the provinces, but Isfahan province has a significant difference with Khorasan Razavi and Mazandaran provinces and has a lower level then them. Khorasan Razavi and Mazandaran provinces have significant differences with Isfahan and Azarbaijan provinces, and the level of long-term orientation are higher. At city Azarbaijan province has a significant difference with Khorasan Razavi, Mazandaran and Khuzestan provinces, and its area is less long-term orientation and Khuzestan province has a significant difference and less uncertainty avoidance. Regarding the constraint there is a significant difference between the densities of constraint index at Tehran and Mazandaran provinces with the provinces of Isfahan and Azarbaijan. Their level of constraint is higher and does not have a significant difference with the rest of the studied provinces. Isfahan province has a significant difference with the provinces of Tehran and Mazandaran, and its constraint level Is less; Khorasan Razavi province has no significant difference with the rest of the studied provinces, Azarbaijan province with the provinces of Tehran and Khuzestan has significant different and the level of constraint is higher in comparing with these two city but not with the rest studied cities.

To answer the fourth question, - What are the appropriate management methods according to the results of the third question? Theoretical resource, ANOVA and Tukey test were used.

Based on the results of Tukey's test, in the cultural index of masculinity, the provinces of Tehran and Mazandaran are the most male- oriented and in the grouping index result shows all studied provinces are above the average. At uncertainty avoidance index results, the provinces of Tehran, Isfahan and East Azerbaijan is high and in The index of power distance of all provinces is at a lower than average level. In the cultural index of long-term orientation, the Khorasan Razavi and Mazandaran provinces, they are more long-term oriented and the cultural factor of the constraint the province's c of Tehran, Khorasan, Mazandaran and Khuzestan more constrained.

So according to the result of these analysis we can say that, the most suitable and appropriate style for the cities with highly level of masculinity index is the competitive management and cooperation style, and for the cities with the higher average of grouping index and low power distance index, the cooperative style is appropriate. High index of ambiguity avoidance requires clarity of instructions and rules in the system and company. Table 5 illustrates the leadership style and issues that should be addressed to them through the cultural differences. 
INTERNATIONAL JOURNAL OF ACADEMIC RESEARCH IN BUSINESS AND SOCIAL SCIENCES

Vol. 9, No. 3, March, 2019, E-ISSN: 222 2-6990 @ 2019 HRMARS

Table 5: Leadership style in Provinces with regard to the cultural differences

\begin{tabular}{|c|c|c|}
\hline Culture index & Provinces & Leadership style \\
\hline Masculinity & Tehran and Mazandaran & $\begin{array}{l}\text { Decisions are made by men, men } \\
\text { are working in all the positions at } \\
\text { company, } \\
\text { employees' assessment is based } \\
\text { on the progress of individuals, } \\
\text { decision-making by the high levels } \\
\text { in company. } \\
\text { Therefore, collaborative and } \\
\text { competitive management styles } \\
\text { are applied. }\end{array}$ \\
\hline Grouping & All the cities at same level & $\begin{array}{l}\text { It's kind of support and } \\
\text { participatory leadership styles. } \\
\text { Work teams are formed; the } \\
\text { atmosphere is friendly. The } \\
\text { assessment of individuals is based } \\
\text { on their commitment, } \\
\text { employee participating in the } \\
\text { work and decision-making } \\
\text { process, for staff families, } \\
\text { concessions are to be made; } \\
\text { extraordinary programs such as } \\
\text { sports programs will be held } \\
\text { Informal groups are formed with } \\
\text { the leaders. }\end{array}$ \\
\hline Uncertainty avoidance & Tehran, Isfahan and Azerbaijan & $\begin{array}{l}\text { The duties and expectations are } \\
\text { clear, certain instructions are } \\
\text { issued, and subordinates are } \\
\text { required to act in accordance with } \\
\text { the rules and regulations, there is } \\
\text { no trustworthiness of the } \\
\text { treasurer and communications } \\
\text { are up-and-down, the instructions } \\
\text { and procedures in the } \\
\text { organization are simple, } \\
\text { transparent and clear, by holding } \\
\text { training courses all duties and } \\
\text { responsibility described. }\end{array}$ \\
\hline Power distance & All the cities at same level & $\begin{array}{l}\text { It is kind of, participatory style, in } \\
\text { which there is full trust and } \\
\text { confidence to subordinates, } \\
\text { communications are in between } \\
\text { the all level of employees, they } \\
\text { want to consult with subordinates } \\
\text { and use their opinions before } \\
\text { making a decision. Organizational } \\
\text { atmosphere is fully friendly and } \\
\text { the leader and mangers are part } \\
\text { of other employs. }\end{array}$ \\
\hline
\end{tabular}


INTERNATIONAL JOURNAL OF ACADEMIC RESEARCH IN BUSINESS AND SOCIAL SCIENCES Vol. 9, No. 3, March, 2019, E-ISSN: 222 2-6990 @ 2019 HRMARS

\begin{tabular}{|l|l|l|}
\hline Long-term orientation & $\begin{array}{l}\text { The duties and expectations are } \\
\text { clear, certain instructions are } \\
\text { issued, and subordinates are } \\
\text { required to act in accordance with } \\
\text { the rules and regulations, they } \\
\text { have a job safety and division of } \\
\text { tasks. }\end{array}$ \\
\hline Constraint & $\begin{array}{l}\text { The leader has relative reliance } \\
\text { on subordinates, takes care of } \\
\text { their well-being and creates a } \\
\text { friendly atmosphere, however, } \\
\text { the organization's policy and } \\
\text { overall decisions are made at the } \\
\text { high levels. }\end{array}$ \\
\hline Tehran, Mazandaran, Khorasan and Khorasan \\
and Khuzestan
\end{tabular}

\section{Conclusion}

Culture is always a collective phenomenon, since at least part of culture is related to people living or doing in the same social environment, learned and educated there. The culture distinguishes members of a group or class of people from each other. Culture is learned and not innate and intrinsic. As we know, culture originates from the social environment of the individual and is learned from birth and is not inherited. Culture is relative, the relativity of culture points to the fact that there is no uncultured person and society (Hofstede, 2009). The results of this study showed that there were different subcultures based on geographic regions, as well as significant cultural differences in provincial different organizations in a country. Also, there are significant cultural differences among the different studies provinces of the country, so according to the result as we saw that all the cities are at the average level in the terms of masculinity just there is different with two cities of Tehran and Mazandaran are more masculinity than the others. Also, all the provinces have more than average level in term of grouping index. About uncertainty avoidance index the provinces Isfahan and Azerbaijan are more ambiguous avoidance in comparing with other cities. All the provinces have a power distance range below the average and all were at the same level, in terms of long-term orientation all has the rate above the average, and the provinces of Khorasan Razavi and Mazandaran are more long-term oriented. All provinces are modest in in the term of constraint index and the provinces of Tehran, Khorasan Razavi, Mazandaran and Khuzestan are more Constrained. The ambiguity avoidance of all the provinces is high, while the high uncertainty avoidance needs more control of the staff and justifies this type of controlled leadership behaviour, however, the employees need a fair distribution of power in all part of organization and the less power distance indicates that the individuals tend to avoid injustice. High grouping reflects the interest of individuals in attending collections and groups, and emphasizes the high level of community presence and social responsibility. Also, the average level of masculinity is a reflection of emotions and feelings controls and it is also shows that individuals in Iranian organizations are paying attention to each other's and their purpose is not only to earn money, progress and reputation but they are attention to the social responsibility too. For this issue first it is recommended for women employees' to be involved in decision making at organization and the recommendations for the executive leaders are to first, use 
more the collaborative and competitive styles to leaded and manage better the men's and women's positions in organization and all employees have to participate in decision making. Second, try emphasize both the quality of work life and the progress of individuals for each employee. Third, use the system of self-control for the performance assessment and also personally controlling of the employees' performance in the organization. Fourth both the soft and intuitive skills of individuals rewarding and encouraging and their civility and their perseverance. Fifth paying attention to cooperation and making the atmosphere of an organization friendly, divided the work between the employees and participate them to process of work, sixth allowing them to comment on the activities and freely talking their opinion about the methods of accomplishing the work, the new idea, new designs and methods are being welcomed to encourage the young employees and at end to improve the quality of work can have held the training and risk management classes.

According to the cultural indicators and result of this research, it can be concluded that, the employees desire is to having a friendly atmosphere in a company, attending in organizational activities, and they have ability to participating in decisions, therefore, it seems that for the Iranian organizations according the four management models of Likert includes, Exploitative, Benevolent, Consultative, Participative-group, a more appropriate model is the Benevolent model that has relative reliance on subordinates, takes care of their well-being and has a friendly atmosphere however, the organization's policy and overall decisions are made at a top level.

It is suggesting to the people in the position of leaders at organization; to understand the interdependencies relations, respond to multiple cultures at a time, be generic, have readiness to share power and have multi-dimensional thinking and learning skills, with sense of satisfaction and happiness, ability to empathy with different cultures and behaviours, he/she should have high selfesteem, be polite and respect for the people's opinions, be flexible and criticized, adaptable to different environmental and cultural conditions existing in any areas. Suggestions for the managers are, to take consider the national, organizational and regional's culture of the organization when making their decision and make decisions according to that cultures. The managers do not to make unilateral decisions and they consider the cultural differences of individuals and decide generalise and systemic. At the evaluation point not only an individual evaluate, also the teamwork and teams has to evaluate and rewarded. Managers, should be trust on their employees and also attracts their trust and them believes. Managers should have a friendly and polite behaviours with their subordinates. Also all the managers and leaders has to trained for better deal and communication with employees with the different culture and at the end should be considered that this research has been carried out in Iran Social Security Insurance Company in the studied provinces and should be generalized to the intervals time and other organizations worked cautiously. Also, it is suggested to other researchers to study the impact of cultural differences in other organizations, even citizens, so by identifying a culture, can make the best decisions for the organization and the society according to its dominant culture.

\section{Reference}

Bolt, J. (2007); Leadership development. [San Francisco, CA]: Pfeiffer.

Florence R. Kluckhohn, Fred L. Strodtbeck, John M. Roberts, A. Kimball Romney, Clyde Kluckhohn, Harry A. Scarr, (1962); Variations in Value Orientations, American Journal of Sociology 68, no. 
INTERNATIONAL JOURNAL OF ACADEMIC RESEARCH IN BUSINESS AND SOCIAL SCIENCES

Vol. 9, No. 3, March, 2019, E-ISSN: 222 2-6990 @ 2019 HRMARS

1, 124-125. https://doi.org/10.1086/223276.

Hofstede, G. (1980); Culture's Consequences: International Differences in WorkRelated Values. Beverly Hills, CA: SAGE.

Hofstede, G. (1984); Cultural dimensions in management and planning. Asia Pacific Journal of Management, 1(2), 81-99. Doi: 10.1007/bf01733682.

Hofstede, G. (2011); Dimensionalizing Cultures: The Hofstede Model in Context. Online Readings in Psychology and Culture, 2(1). https://doi.org/10.9707/2307-0919.1014.

Matsumoto, D., \& Hwang, H. (2013); Assessing Cross-Cultural Competence. Journal of Cross-Cultural Psychology, 44(6), 849-873. Doi: 10.1177/0022022113492891.

Armstrong, M. (2001); Strategic Human Resource Management: A Guide to Action. $4^{\text {th }}$ Edition.

Rezaeian, A. (2004); the basic of organizational behavior management, $4^{\text {th }}$ edition, Tehran, SAMT Publication.

Reardon, J., \& Miller, C. (2012); The effect of response scale type on cross-cultural construct, measures. International Marketing Review, 29(1), 24-53. doi: 10.1108/02651331211201534.

Robbins, S. (2017); Essentials of organizational behaviour plus my lab management with Pearson e text access card. Prentice hall.

Susan, C. S. \& Barsoux, J. (2014); Managing Across Cultures. Prentice-Hall. Trompenaars, F. \& Hampden-Turner, C. (1998); Seven dimensions of culture. Culture and Internationalization.

Available from: http://www.provenmodels.com/580/sevendimensions-of-culture/charleshampden-turner--fons-trompenaars [Accessed 2012], 1-4. 